This is an electronic reprint of the original article. This reprint may differ from the original in pagination and typographic detail.

Author(s): Uibu, Krista; Salo, Age; Ugaste, Aino; Rasku-Puttonen, Helena

Title: $\quad$ Beliefs about teaching held by student teachers and school-based teacher educators

Year: $\quad 2017$

Version:

Please cite the original version:

Uibu, K., Salo, A., Ugaste, A., \& Rasku-Puttonen, H. (2017). Beliefs about teaching held by student teachers and school-based teacher educators. Teaching and Teacher Education, 63(April), 396-404. https://doi.org/10.1016/j.tate.2017.01.016

All material supplied via JYX is protected by copyright and other intellectual property rights, and duplication or sale of all or part of any of the repository collections is not permitted, except that material may be duplicated by you for your research use or educational purposes in electronic or print form. You must obtain permission for any other use. Electronic or print copies may not be offered, whether for sale or otherwise to anyone who is not an authorised user. 


\title{
Beliefs about teaching held by student teachers and school-based teacher educators
}

\author{
Krista Uibu a, Age Salo a, *, Aino Ugaste b, Helena Rasku-Puttonen c \\ a Institute of Education, University of Tartu, Tartu, Estonia \\ b School of Educational Sciences, Tallinn University, Tallinn, Estonia \\ c Department of Teacher Education, University of Jyväskylä, Jyväskylä, Finland
}

\begin{abstract}
Teachers' beliefs about teaching goals and practices are influenced by several factors, including teaching and mentoring experiences. To identify which teaching goals and practices are preferred for the social and cognitive development of pupils, 112 student teachers and 73 school-based teacher educators were questioned. In contrast to teacher educators, student teachers consider the mechanical acquisition of knowledge and practices that support intrapersonal processes directed toward cognitive development to be a more effective goal, while teachers with mentoring experience prefer teaching practices that support pupils' social development. Knowledge about teaching-related beliefs is essential for promoting effective teacher training.
\end{abstract}

Keywords: student teachers, teacher educators, teachers' beliefs, teaching practices, teacher education

\section{Introduction}

In many countries, including Estonia, school-based teacher educators constantly work with student teachers during their pre-service school practice, thus playing a key role in teacher training (European Commission/EACEA/Eurydice, 2015). The purpose of school-based teacher educators is to model the teacher role through their own teaching and provide an example to student teachers for implementing teaching practices that support the cognitive and social development of pupils (Jaspers, Meijer, Prins, \& Wubbels, 2015; Lunenberg, 2010). Despite the complexity of this phenomenon, research has been conducted on which repertoire of teaching goals and practices are related to teachers' beliefs about teaching (Devine, Fahie, \& McGillicuddy, 2013; de Vries, van de Grift, \& Jansen, 2014; Khader, 2012; Mansour, 2009; Pajares, 1992). The repertoire is also situated within the larger social and cultural context (John-Steiner \& Mahn, 1996).

In accordance with theoretical perspective, the sociocultural context impacts individuals' ways of thinking and acting and is thereby essential to both learning and teaching (van Huizen, van Oers, \& Wubbels, 2005). Beliefs about teaching are also related to their sociocultural context at different levels, ranging from the classroom to the culturalinstitutional environment (Fives \& Buehl, 2012). When setting teaching goals and choosing 
teaching practices, teachers may rely on beliefs developed in particular sociocultural contexts (Mansour, 2009). However, although changes in the contexts may happen quickly, teachers' beliefs about teaching tend to change more slowly due to their many years of teaching experience (Pajares, 1992). This tendency may obstruct teachers' readiness to establish contemporary teaching goals and use novel teaching practices that facilitate the development of intrapersonal and interpersonal processes (Espasa \& Meneses, 2010; Khader, 2012; Tatto $\&$ Coupland, 2003). Moreover, school-based teacher educators' established beliefs may have an undesirable effect on their instruction of student teachers (Lunenberg, Korthagen, \& Swennen, 2007) and in contemporary teacher education more generally (Hobson, Ashby, Malderez, \& Tomlison, 2009).

Studies of the beliefs and practices of student teachers and school-based teacher educators have yielded inconsistent results. Teachers, for example, appear to focus more on cognitive development goals, setting aside pupils' social development (OECD, 2014; Uibu \& Kikas, 2014). Research has also been conducted on which student teachers attach importance to teaching practices directed toward mechanical acquisition without considering the importance of practices that promote social skills (Sandholtz, 2011; Thomson, Turner, \& Nietfeld, 2012). Compared to student teachers, teacher educators focus more on the social development of pupils (He \& Levin, 2008; Salo, Uibu, Ugaste, \& Rasku-Puttonen, 2015). As beliefs have a reciprocal relationship with context and experiences (Fives \& Buehl, 2012), the formation of student teachers' beliefs is therefore related to real school practice $(\mathrm{Ng}$, Nicholas, \& Williams, 2010). For this reason, it is vital to more thoroughly analyze the beliefs of student teachers and teacher educators about teaching goals and practices (Rozelle \& Wilson, 2012), especially since such beliefs may have a significant effect on the success of students' pre-service school practices (He \& Levin, 2008) as well as the entire teacher training system (Tillema, Smith, \& Leshem, 2011).

Thus, the purpose of this study was to investigate the beliefs of student teachers and school-based teacher educators about teaching goals and teaching practices, as well as the beliefs of school-based teacher educators who have had different mentoring experiences. The study was conducted in Estonia, a country where diametrically opposed paradigms, beliefs, and values are evident in the educational system (Uibu \& Kikas, 2014) and where the majority of current teachers and school-based teacher educators completed their teacher training during the Soviet period (Ruus et al., 2008; Toomela \& Kikas, 2012). 


\subsection{Sociocultural approach in teaching}

According to the sociocultural framework, teaching goals and associated practices are applied primarily to the learning and teaching process. Yet, while goals determine the direction of teaching, teachers are not always aware of which teaching practices they can use to achieve certain goals. Previous research has shown that teachers' knowledge about student development is not sufficiently thorough, nor do some teachers appear to be competent enough to explain their teaching goals (Vaughn, 2014; van Velzen \& Volman, 2009). When deciding on which teaching practices to use, teachers should consider both social and cognitive development goals, the balance of which might be the best approach for promoting effective instruction (Hofman, Hofman, \& Guldemond, 1999).

On the basis of a revised taxonomy of educational objectives, a child's development is considered hierarchical: the prerequisite for acquiring higher-level skills is the prior acquisition of lower-level skills (Krathwohl, 2002). Without having the necessary skills, a child cannot comprehend the task at hand nor rely on prior knowledge (Vygotsky, 1978). A teacher's task is to use dialogue to support pupils' active construction and acquisition of new knowledge (Eun, 2010). Social communication and the cognitive development of pupils are interrelated, as the success of teaching is determined by the nature of the connection between teachers and pupils (Stone, 1993). Therefore, the sociocultural approach to teaching emphasizes communicative processes - teaching depends on teacher-pupil interaction. Teachers should also pay greater attention to social development in order to make sure that pupils are provided with the self-management skills needed to effectively adapt to different environments (Zwaans, van der Veen, Wolman, \& ten Dam, 2008).

To achieve teaching goals and cultivate various competencies in students, teachers implement different teaching practices. Teaching practices can be defined as a set of instructional methods and strategies employed in teacher-student interaction in the classroom (Khader, 2012). In choosing teaching practices, it is essential to consider a child's zone of proximal development - that is, gauging the distance between a child's levels of independent and supported performance makes it possible to plan a more effective teaching strategy (Vygotsky, 1978). When devising teaching practices, the teacher's aim should be to create a bridge between what the child is capable of doing independently and what he or she requires assistance doing.

In order to enhance the cognitive and social development of pupils, the teaching practices of teachers should support intrapersonal and interpersonal processes (Espasa \& 
Meneses, 2010). Based on Vygotsky's conception of learning, interpersonal processes involve the use and exchange of different mental tools (e.g., language, texts, formulas) in communication with other people, while intrapersonal processes entail both the acquisition of mental tools and the ability to employ them independently (Bodrova \& Leong, 2007). Intrapersonal processes are supported by teaching practices that focus on the development of pupils' self-evaluation and effortful cognition skills, both of which can be used for understanding and drawing connections between current learning and prior knowledge (McCaslin \& Hickey, 2001). However, when pupils express ideas or compare their learning to peers, the teaching practices that shape intrapersonal processes also influence the pupils' social development (Oldfather \& Dahl, 1994). Teaching practices aimed at the formation of interpersonal processes, on the other hand, facilitate the social development of learners as well as the development of cooperative skills (Schmuck \& Schmuck, 1975). Teachers can enhance the interpersonal processes of pupils by, for instance, providing feedback, which can accelerate their cognitive development (Espasa \& Meneses, 2010). According to sociocultural theory, the task of teachers is to keep in mind that teaching practices are not used in isolation but are interconnected: goals pertaining to both the cognitive and social development of learners should be considered together (John-Steiner \& Mahn, 1996).

\subsection{The beliefs of student teachers and teacher educators}

A teacher's beliefs are a form of personal knowledge that can be viewed as implicit perspectives on learning, pupils' development, and the subject matter being taught (Fives \& Buehl, 2012; Kagan, 1992). Deemer (2004) pointed out that prevailing beliefs related to learning at school influence the way teachers define the purposes of learning in their classrooms. A change in the educational context requires a concomitant change in teaching practices, and both pre- and in-service teachers must be prepared to respond to such a change (Valcke, Sang, Roths, \& Hermans, 2010). However, as a system, teacher beliefs are situated within larger contexts and are relatively stable across settings and times (Fives \& Buehl, 2012; Valcke et al., 2010). Due to their long-lasting and resilient nature, beliefs can prevent changes in the teaching process (Pajares, 1992). Moreover, the beliefs of experienced teachers are more resistant to change than those of younger teachers, as experienced teachers are typically more confident about their instructional skills (Rubie-Davies, Flint, \& McDonald, 2012). 
Promoting changes in the beliefs of student teachers is considered essential, since their beliefs are often based on personal learning experiences and can be too optimistic; such beliefs do not promote effective teaching (Thomson et al., 2012). The need to overcome the disparity between the ideal teaching model and actual teaching experience results in changes in beliefs after the first teaching experience, whereby beliefs become associated with the actual teaching process ( $\mathrm{Ng}$ et al., 2010). In addition to teaching experience, the beliefs of school-based teacher educators about teaching have an impact on the beliefs of student teachers as well (Valcke et al., 2010). School-based teacher educators convey not only personal teaching experiences but also school culture and values, thereby providing student teachers with the necessary qualities for effective teaching. Student teachers may recognize the school-based teacher educators' beliefs when they have a positive teaching experience, or they may seek new solutions should the beliefs of teacher educators fail to promote effective teaching (Rozelle \& Wilson, 2012).

As a rule, school-based teacher educators are experienced teachers. Teachers with more teaching experience have a better comprehension of teaching and the purposes of different teaching practices (Liu, Jones, \& Sadera, 2010). Some teachers consider the transfer of academic knowledge to be of primary importance (Lasky, 2005), while others pay more attention to problem-solving skills and enhancing social development (de Vries et al., 2014; Kuzborska, 2011). Teachers who consider social interaction to be critical to learning value pupils asking for help from either them or their peers (Stipek, Givvin, Salmon, \& MacGyvers, 2001). Further, a mentoring experience may affect a teacher's awareness of instructional processes, objectives, and practices (Jaspers et al., 2014). Contemporary teaching methods implemented by student teachers during their school-based practice may encourage schoolbased teacher educators to promote such methods as well (White, Dickerson, \& Weston, 2015). Also, because they are viewed as role models by student teachers, school-based teacher educators pay more attention to preparing and reflecting on their method of instruction (Simpson, Hastings, \& Hill, 2007). Still, previous studies have not demonstrated that teachers with longer teaching experience are more effective at mentoring (Killian \& Wilkins, 2009). The majority of teachers do not see the potential to advance their professional development and careers by mentoring (Simpson et al., 2007). This view may be the reason for little effect on school-based teacher educators' beliefs and practices. 


\subsection{Context of Estonian teachers' beliefs}

Changes in the Estonian social structure in the last two decades have necessitated the reformation of the national curriculum for general education (Viirpalu, Krull, \& Mikser, 2014) as well as the teacher training system (Toomela \& Kikas, 2012). Based on the updated curriculum, teachers are now expected to apply practices that will enhance pupils' ageappropriate cognitive and social development and model real-world situations from the surrounding environment (Estonian Government, 2011). According to the Estonian National Lifelong Learning Strategy (Estonian Government, 2014), it is important to implement a teaching approach in schools that values and supports interpersonal processes and cooperation between both pupils and colleagues. However, not all teachers have adapted to these changes; on the contrary, some have altogether ignored them because their personal pedagogical beliefs and practices are grounded in former sociocultural norms and values incompatible with the principles of the updated curriculum (Loogma, Tafel-Viia, \& Ümarik, 2013; Tuul, Ugaste \& Mikser, 2011).

Experienced teachers who graduated from universities during the Soviet period have stated that they do not find it difficult to incorporate contemporary teaching practices to promote teaching (Meristo, Ljalikova, \& Löfström, 2013). Thus, they implement up-to-date knowledge, communicative strategies and active teaching practices in their instruction relatively more often than younger teachers (Ruus et al., 2008). However, the results of the TALIS 2013 survey have revealed a gap between Estonian teachers' beliefs and practices (OECD, 2014). Compared to teachers in other countries, Estonian teachers do not appear as eager to implement active teaching practices; although they place high value on pupils' cognitive development, they tend to overlook social development goals (OECD, 2014; Uibu \& Kikas, 2014). The former educational paradigm has left its mark on many teachers, and the beliefs they acquired during the Soviet period may continue to impact their choice of teaching practices (Uibu, Kikas, \& Tropp, 2011).

In recent years, changes in the teacher training curriculum at universities and the quality of teacher training programs have gained more attention (Eisenschmidt, 2011). Like other European countries, since 2006 Estonian universities have followed the Bologna process in organizing teaching and the bachelor-master system of study modules (European Commission/EACEA/Eurydice, 2015; Jakku-Sihvonen, Tissari, Ots, \& Uusiautti, 2012). Contemporary teacher education comprises general studies, subject studies, and practical training. Student teachers generally have a good theoretical background in terms of active 
teaching, and experienced teachers should be capable of successfully instructing student teachers (Löfström \& Poom-Valickis, 2013). However, student teachers' pedagogical practice does not always integrate knowledge acquired at the university level (Timoštšuk \& Ugaste, 2010). In a situation where teaching-related beliefs among student teachers have not yet been clearly formed, school-based teacher educators can influence student teachers' perceptions about teaching more than university-based educators, who generally provide students with single lessons and theoretical advice (Eisenschmidt, 2011; Löfström \& Poom-Valickis, 2013). Although pre-service teacher training in Estonia has been reformed several times, little emphasis has been placed on school-based teacher educators' training and mentoring skills. Estonian universities do not even organize mentor training programs for school-based teacher educators before they start supervising pre-service students' school practice.

\subsection{Aims and hypotheses}

The aim of the current study was to investigate the beliefs of student teachers and schoolbased teacher educators, as well as the beliefs of school-based teacher educators with different mentoring experiences, with regard to the goals and teaching practices critical to the social and cognitive development of pupils. The following research questions and hypotheses were formulated:

1. To what extent do the beliefs of student teachers and school-based teacher educators, which are based on teaching experience, vary in regard to the cognitive and social development goals for pupils? Earlier studies have shown that student teachers' beliefs about teaching goals may change after their first teaching experience; furthermore, they tend to focus more on the development of pupils' social skills ( $\mathrm{Ng}$ et al., 2010). In contrast, teachers pay more attention to goals related to the cognitive development of pupils (Devine et al., 2013). But, according to Sayeski and Paulsen (2012), teacher educators who have mentored student teachers also aim to develop the social skills of pupils. We hypothesized that student teachers and school-based teacher educators have different beliefs regarding goals related to the cognitive and social development of pupils based on their relative teaching experiences; likewise, we predicted differences between the beliefs of teachers who had and who did not have mentoring experience.

2. What are the differences between student teachers' and school-based teacher educators' beliefs about teaching practices that support intrapersonal and interpersonal processes used to guide the cognitive and social development of pupils? 
Some studies have demonstrated similarities between school-based educators' and student teachers' beliefs; for example, both value cooperation-based teaching (Wilke \& Losh, 2008). However, it has also been found that student teachers' and schoolbased teacher educators' beliefs about teaching practices still differ (Rozelle \& Wilson, 2012). Therefore, we supposed that student teachers and teacher educators reveal differences in their beliefs about teaching practices that support intrapersonal and interpersonal processes focused on the cognitive and social development of pupils. Furthermore, as school-based educators' beliefs about teaching rest on previous experience (van Velzen \& Volman, 2009), we predicted divergence between the beliefs of teachers who had and who did not have mentoring experience about teaching practices that enhance pupils' intrapersonal and interpersonal processes.

\section{Method}

\subsection{Participants and procedures}

Data were gathered from 112 student teachers (89 females and 23 males) from Estonian universities and 73 teachers (66 females and 7 males) who had been involved in an unprecedented training program, organized by Estonian universities, for teachers to supervise student teachers. The average age of the student teachers was 24.8 years $(S D=5.17)$, while for teachers it was 42.4 years $(S D=9.97)$.

The participating students had graduated from bachelor's studies in their subjects in different university departments and had never taken any teacher education courses. Since some of the student teachers had been working as teachers in schools, they were divided into two groups according to their teaching experience. The number of students with no teaching experience was 91 (81.3\%), while the number of students with teaching experience was 21 (18.7\%). Student teachers' teaching experience varied from 1 to 5 years $(M=1.5, S D=.98)$.

School-based teacher educators' teaching experience varied from 1 to 38 years $(M=$ 17.2, $S D=9.48$ ). Based on teaching experience, they were divided into three groups. The first group of teachers, with teaching experience ranging from 1 to 5 years (hereafter: TEG 1), comprised $16.4 \%$ of respondents. The second group of teachers, with teaching experience ranging from 6 to 20 years (hereafter: TEG 2), comprised $47.9 \%$ of respondents. Teachers with 21 or more years of experience were placed in the third group, TEG 3 (35.7\% of respondents). The average duration of teaching experience for teachers without mentoring experience $(24.7 \%$ of respondents) was 9.6 years $(S D=7.93)$; for teachers with mentoring 
experience ( $75.3 \%$ of respondents), the average duration of teaching experience was 19.7 years $(S D=8.62)$.

The data concerning student teachers' beliefs about teaching goals and practices were gathered before their enrolment in the pre-service teacher training program. In the case of teacher educators, they completed the same questionnaire about beliefs as student teachers at the beginning of the school-based teacher educator training program. The questionnaire took approximately 20 minutes to complete and was organized by members of the university teacher training research team.

\subsection{Questionnaire}

The questionnaire on teachers' beliefs about teaching goals and practices related to the cognitive and social development of pupils was developed on the basis of a revised taxonomy of educational objectives (Krathwohl, 2002), National Curriculum requirements (Põhikooli riiklik õppekava, 2011), and previous studies (Uibu \& Kikas, 2014; Uibu et al., 2011). An initial exploratory factor analysis with 187 teachers was carried out (see Salo et al., 2015). The suitability of items included in the questionnaire was discussed with a group of teacher educators and practitioner teachers. The questionnaire was then piloted to assess the appropriateness of every item in both the student teacher and school-based teacher groups. The respondents had to select the goals that matched teaching practices related to pupils' cognitive or social development. Before completing the questionnaire, participants filled out a form with their background information.

The first part of the questionnaire included 10 descriptions of teaching practices followed by a multiple-choice list of teaching goals related to the cognitive development of pupils (10 items). The goals covered three domains of learning: mechanical acquisition (three goals, e.g., to develop the ability to retain information), implementation (three goals, e.g., to develop thinking skills), and generalization (four goals, e.g., to develop problem-solving skills). The second part of the questionnaire included seven teaching practices followed by a list of goals related to the development of social skills (eight items). This list included three domains: independence (three goals, e.g., to support pupils' initiative), reflexive skills (three goals, e.g., to support efficient learning), and social competence (two goals, e.g., to support the development of appropriate behavior patterns). Examples of both parts of the questionnaire are provided in the Appendix. 
The teaching practices associated with cognitive as well as social development goals were divided, in turn, into two domains: (1) practices supporting pupils' intrapersonal processes, and (2) practices enhancing pupils' interpersonal processes. First, teaching practices related to cognitive development and intrapersonal processes were maintained for pupils' individual development (seven items, e.g., to encourage pupils to resolve problems independently). Second, practices related to proceeding from cognitive development and promoting interpersonal processes were focused on discussion and cooperation between pupils and teachers (three items, e.g., to promote discussions related to the topic). Third, teaching practices directed toward social development goals and the enhancement of intrapersonal processes were aimed at pupils' self-evaluation, focusing on feasible tasks and behaviors (four items, e.g., to enable pupils to do a lot of independent work). Fourth, practices related to social development goals and the encouragement of interpersonal processes were aimed at cooperation with peers (three items, e.g., to encourage interaction between pupils).

The answers were coded separately for each teaching goal and teaching practice according to whether they were selected (1) or not selected (0). After that, the number of goals pertaining to pupils' cognitive and social development chosen by each respondent for each teaching practice was counted, and the number of all teaching practices used for each specific teaching goal was summarized (see Kline, 2005). The maximum score for cognitive development goals was 10; for social development, the maximum score was eight. Internal consistencies (Cronbach's $\alpha$ ) were calculated for the items of the aforementioned domains and are presented in Table 1 (see below).

\subsection{Data analysis}

In order to ascertain differences between the beliefs of student teachers and school-based teacher educators, a descriptive analysis was first carried out. An analysis of variance (oneway ANOVA) and post hoc analysis with a Bonferroni correction were used to analyze differences between teaching goals and teaching practices valued by student teachers and school-based teacher educators. The one-way ANOVA was also used to analyze differences between the beliefs of school-based teacher educators with or without mentoring experience with regard to teaching goals and teaching practices. In order to present statistical significance as well as the $p$-value, an effect size of partial $\eta^{2}$ (further: $\eta^{2}$ ) was used: 0.01 - small effect; 0.06 - moderate effect; 0.14 - large effect (see Cohen, Manion, \& Morrison, 2011). The SPSS 22.0 was used for the data analysis. 


\section{Results}

To examine the beliefs of student teachers and school-based teacher educators with regard to teaching goals and teaching practices associated with the cognitive and social development of pupils, a descriptive analysis was carried out (Table 1).

- Insert Table 1 about here -

We examined the extent to which the beliefs of student teachers who had or who did not have teaching experience as well as the beliefs of school-based teacher educators of different experience groups varied in regard to pupils' cognitive and social development goals. The differences in the beliefs were analyzed using a 5 (groups of respondents) $\mathrm{x} 3$ (domain of a goal) one-way ANOVA. The analysis showed that there were significant differences with respect to teaching goals, with a moderate effect size between the beliefs of student teachers and school-based teacher educators concerning goals in the domain of mechanical acquisition: $F(4,184)=4.98, p=.001, \eta^{2}=.100$. In order to identify the groups whose results were significantly different, the Bonferroni test was used as a post hoc analysis. The results revealed that students without teaching experience preferred teaching goals in the domain of mechanical acquisition significantly more than teachers in groups TEG $2(p=.010)$ and TEG $3(p=.033)$. An analogous difference was also revealed between the beliefs of students with teaching experience and teachers in group TEG 2 with respect to teaching goals in this domain $(p=.047)$. However, no differences between the five groups of respondents in their preferences for social development domains were found.

We next analyzed the extent to which the beliefs of teachers who had and who did not have mentoring experience differed with respect to the cognitive and social development goals for pupils (see Table 2 for descriptive statistics).

\section{- Insert Table 2 about here -}

It appears that, with a moderate effect size, teachers with mentoring experience considered teaching goals in the social development domain of social competence to be more essential: $F(1,71)=6.01, p=.017, \eta^{2}=.078$. A statistically significant difference with a moderate effect size was also indicated in pupils' social development domain of reflexive skills: $F(1$, $71)=5.27, p=.025, \eta^{2}=.069$. Thus, teachers with mentoring experience approved of more teaching goals for supporting reflexive skills. 
We were also interested in differences between student teachers' and school-based teacher educators' beliefs about teaching practices that support intrapersonal and interpersonal processes used to guide pupils' cognitive and social development (see Table 1 for means and $S D s$ for the five groups). A statistically significant difference with a moderate effect size was found between the beliefs of student teachers and teacher educators with regard to teaching practices that shape intrapersonal processes toward the cognitive development of pupils: $F(4$, $180)=3.06, p=.018, \eta^{2}=.064$. The post hoc Bonferroni test yielded a marginal difference between the beliefs of students with teaching experience and teachers in group TEG 2 ( $p=$ .051). Thus, the students in this group preferred teaching practices that support intrapersonal processes used to guide pupils' cognitive development. In regard to beliefs about practices that enhance intrapersonal and interpersonal processes related to pupils' social development, no statistically significant differences between groups of students and teachers were found.

In addition, we analyzed differences between the beliefs of teachers who had and who did not have mentoring experience in regard to teaching practices that encourage pupils' intrapersonal and interpersonal processes (Table 3).

- Insert Table 3 about here -

A disparity with a moderate effect size was discovered. Teachers with mentoring experience preferred teaching practices that support the social development goals for pupils in the domain of practices aiding intrapersonal processes more than teachers without such experience: $F(1$, $71)=5.99, p=.017, \eta^{2}=.078$.

\section{Discussion}

Studies of the teaching-related beliefs of student teachers and school-based teacher educators have helped to explain how both groups interpret their work and promote teacher education and instruction. The current study revealed that compared to school-based teacher educators, student teachers prefer teaching goals focused on the mechanical acquisition of knowledge and teaching practices that support intrapersonal processes used to guide the cognitive development of pupils. In addition, teachers with mentoring experience value teaching practices that enhance intrapersonal processes related to the achievement of social development more than teachers without mentoring experience. 
The assumption that beliefs about pupils' development goals differ between student teachers and school-based teacher educators was confirmed only for the cognitive development domain of mechanical acquisition. Further, our study did not reveal significant differences in beliefs about teaching goals between students who had some teaching experience and students who did not. Both groups of students appeared to place greater emphasis on mechanical acquisition than teachers with longer teaching experience. In her study, Sandholtz (2011) also mentioned that many student teachers overestimate the teaching of facts. Student teachers feel inadequate in terms of subject knowledge and therefore focus more on knowledge transfer ( $\mathrm{Ng}$ et al., 2010). In addition, student teachers often develop their beliefs about teaching goals based on their own school experiences (He \& Levin, 2008; Thomson et al., 2012). Moreover, the sociocultural context should be not overlooked. Student teachers' beliefs about teaching may be partially grounded in a conception, still prevalent in the society, according to which a school is seen as a place for transferring knowledge, and a successful pupil is viewed as one who follows rules and norms (Sakk, 2014; Sandholtz, 2011). In the case of Estonia, student teachers have traditionally taught at schools according to a curriculum that emphasizes cognitive development goals for pupils. As these beliefs are based to a great extent on personal learning experience (Thomson et al., 2012), they often affect student teachers' instructional perceptions and solutions (see Toomela \& Kikas, 2012).

No differences were evident between the beliefs of student teachers and school-based teacher educators in regard to pupils' social development. Teachers may not consider social development to be an independent objective if the link between promoting social competences and subject-related goals is not understood (Zwaans et al., 2008). At the same time, some student teachers consider the promotion of pupils' social development as one of the most important teaching goals (Thomson et al., 2012). In addition, earlier studies have revealed that teachers focus on cognitive rather than social development in pupils in order to support their ability to cope with curriculum requirements (OECD, 2014; Uibu \& Kikas, 2014). Although the curriculum for general education in Estonia has been reformed several times, many teachers are reluctant to adapt to changes made to teaching goals, which could be explained by Estonian teachers' incomplete knowledge of the updated curriculum (Viirpalu et al., 2014).

It was also predicted that teachers who had and who did not have mentoring experience would have different beliefs about the cognitive and social development goals for pupils. Despite living within the same sociocultural context, teachers with mentoring experience appear to consider the social competence and reflexive skills of pupils to be more important than teachers without mentoring experience. There may be several reasons for this 
difference. First, some teachers may lack the requisite knowledge needed to focus on social development goals for pupils (Zwaans et al., 2008). Second, teachers with mentoring experience are more often involved in communication as a social practice. Moreover, when instructing student teachers, teacher educators pay more attention to the social context of teaching and can comment on their experience on that basis (van Velzen \& Volman, 2009). As such beliefs have a communicative background, teachers with mentoring experience can better perceive the influence of teaching practices on students' beliefs and instruction (Killian \& Wilkins, 2009). Third, working conditions, school contexts, and organizational culture may either sufficiently support or obstruct teachers' professional development and career progress (Eisenschmidt, 2011).

Continuing the previous point, a teacher's mentoring experience did not correspond to any difference in goals related to pupils' cognitive development. To some extent, this result may be related to a problem referred to in other studies: the inability of some teachers to connect their knowledge and beliefs about teaching with their teaching experience (Lunenberg et al., 2007; van Velzen \& Volman, 2009). We can assume that in this case, teaching experience may not be associated with beliefs, and that beliefs about pupils' cognitive development remain unchanged after instruction. This could be explained by the fact that cognitive development has become firmly established in the Estonian national curriculum and has thus also become more comprehensible and valued in Estonian society (Uibu \& Kikas, 2014). Also, the good results achieved by pupils in international studies (e.g., the Programme for International Student Assessment [PISA]) may have reinforced the belief among Estonian teachers that it is correct to support cognitive development (OECD, 2014).

We also inquired about the differences between student teachers' and school-based teacher educators' beliefs about teaching practices. The hypothesis that student teachers and school-based teacher educators express different beliefs about teaching practices that enhance the intrapersonal and interpersonal processes which support the cognitive and social development of pupils was partly confirmed. It appears that the beliefs of student teachers and school-based teacher educators differ with regard to practices that support intrapersonal processes aimed at the cognitive development of pupils. However, differences between preferences for teaching practices that promote the social development of pupils were not revealed. On the one hand, it could be argued that since teaching experience provides a better perception of practices that support pupils' development (Liu et al., 2010), experienced teachers will more often prefer those practices that support intrapersonal processes. On the other hand, it has been observed that more experienced teachers tend to use habitual teaching 
practices (Rubie-Davies et al., 2012). Even though teachers consider it important to guide students toward communicating and solving tasks in cooperation with their peers, they tend to predominantly focus on acquiring knowledge. Teachers are often unable to achieve integration of teaching practices based on both cognitive and social development goals, and instead associate the chosen practice with the goal of a single aspect of development (Vaughn, 2014). The reason why students' and teachers' beliefs about teaching practices aimed at social development goals do not differ may be due to the lack of knowledge about the nature of effective teaching. Cognitive development is related to social communication and pupilteacher and pupil-peer interaction is necessary for these purposes (Stone, 1993).

In addition, we expected differences between the beliefs held by teachers who had and who did not have mentoring experience about teaching practices that facilitate pupils' intrapersonal and intrapersonal processes. Teachers with mentoring experience appear to prefer practices that enhance pupils' interpersonal processes for goals associated with their social development. The current study indicates that teachers with mentoring experience consider the social development of pupils more important than teachers without such experience; it is clear, then, that the former group places more emphasis on the relevant teaching activities. This outcome is in accordance with a study conducted by Liu et al. (2010) in which teachers who had different teaching or mentoring experiences were found to be more skillful in a variety of teaching practices while also valuing the social development of pupils to a greater extent. Mentoring experience can support teachers' understanding of teaching as a sociocultural process (Jaspers et al., 2014) and help them better appreciate communication and cooperation as basic components of student development. Our opinion is that teacher educators who work with student teachers have more of an eye toward collaboration. Teaching practices used by student teachers during their school practice may encourage even those teachers with extensive experience to assess new solutions (Simpson et al., 2007; White et al., 2015).

Some methodological limitations of the current study should be considered. Although the students who participated in the study were rather homogenous of their beliefs, greater heterogeneity was observed for teachers. Additionally, the number of participants specifically assigned to different teaching experience groups was quite low. Therefore, more student teachers and school-based teacher educators should be involved in future studies. Second, this study did not consider characteristics such as the subjects taught by teachers, educational levels, or types of schools. Distinctions in teachers' and students' beliefs in relation to these variables should also be assessed. Third, teachers were questioned at the beginning of mentor 
training programs at the universities. To determine how mentoring experience alters teachers' beliefs about teaching and supervising students, a longitudinal study with several research methods and measurement instruments is recommended.

\section{Conclusions}

The present study contributes a comparative perspective on teacher education that helps to clarify the differences and similarities between the beliefs and knowledge of school-based teacher educators and student teachers. More knowledge about teaching-related beliefs held by school-based teacher educators is essential to promote innovation in teacher education and ensure effective school practice during teacher training. This study revealed that school-based teacher educators' training and suitability to supervise student teachers require more attention from universities. Systemic mentor training, arranged by universities, is recommended for school-based teacher educators supervising pre-service teachers' school practice.

Another contribution of this study is that it indicates a lack of teacher training with respect to teachers' readiness to support the social development of pupils. Teachers have to consider both social and cognitive development goals and consciously apply teaching practices aimed at the formation of interpersonal and intrapersonal processes that can support pupils' cognitive and social development. A research topic that warrants further study is the

affinity between teachers' beliefs about teaching and their actual teaching practices, as beliefs do not always reflect activities in the classroom. This divergence might be the reason for universities to implement effective teacher training programs.

\section{References}

Bodrova, E., \& Leong, D. J. (2007). Tools of the mind: A Vygotskian approach to early childhood education. Columbus, OH: Merrill/Prentice-Hall.

Cohen, L., Manion, L., \& Morrison, K. (2011). Research methods in education (7th ed.). London, UK: Routledge.

Deemer, S. (2004). Classroom goal orientation in high school classrooms: Revealing links between teacher beliefs and classroom environments. Educational Research, 46(1), 73-90.

Devine, D., Fahie, D., \& McGillicuddy, D. (2013). What is 'good' teaching? Teacher beliefs and practices about their teaching. Irish Educational Studies, 32(1), 83-108.

de Vries, S., van de Grift, W. J., \& Jansen, E. P. (2014). How teachers' beliefs about learning and teaching relate to their continuing professional development. Teachers and Teaching: Theory and Practice, 20(3), 338-357. 
Eisenschmidt, E. (2011). Teacher education in Estonia. In M. Valenčič Zuljan, \& J. Vogrinc (Eds.), European dimensions of teacher education - Similarities and differences (pp. 115-132). Ljubljana: University of Ljubljana.

Espasa, A., \& Meneses, J. (2010). Analysing feedback processes in an online teaching and learning environment: An exploratory study. Higher Education, 59(3), 277-292.

Estonian Government. (2011). National Curriculum for Basic Schools. Riigi Teataja I, 1. Retrieved from https://www.riigiteataja.ee/en/eli/524092014014/consolide

Estonian Government. (2014). National Lifelong Learning Strategy (2014-20). Retrieved from http://www.kogu.ee/wpcontent/uploads/2014/05/Lifelong-Learning.pdf

Eun, B. (2010). From learning to development: A sociocultural approach to instruction. Cambridge Journal of Education, 40(4), 401-418.

European Commission/EACEA/Eurydice. (2015). The Teaching Profession in Europe: Practices, Perceptions, and Policies. Eurydice Report. Luxembourg: Publications Office of the European Union.

Fives, H., \& Buehl, M. (2012). Spring cleaning for the "messy" construct of teachers' beliefs: What are they? Which have been examined? What can they tell us? In K. R. Harris, S. Graham, \& T. Urdan (Eds.), APA Educational Psychology Handbook (Vol. 2, pp. 471-499). Washington: American Psychological Association.

He, Y., \& Levin, B. B. (2008). Match or mismatch? How congruent are the beliefs of teacher candidates, cooperating teachers, and university-based teacher educators? Teacher Education Quarterly, 35(4), 37-55.

Hobson, A. J., Ashby, P., Malderez, A., \& Tomlinson, P. D. (2009). Mentoring beginning teachers: What we know and what we don't. Teaching and Teacher Education, 25(1), 207-216.

Hofman, R. H., Hofman, W. A., \& Guldemond, H. (1999). Social and cognitive outcomes: A comparison of contexts of learning, school effectiveness and school improvement. International Journal of Research, Policy and Practice, 10(3), 352-366.

Jakku-Sihvonen, R., Tissari, V., Ots, A., \& Uusiautti, S. (2012). Teacher education curricula after the Bologna process-a comparative analysis of written curricula in Finland and Estonia. Scandinavian Journal of Educational Research, 56(3), 261-275.

Jaspers, W. M., Meijer, P. C., Prins, F., \& Wubbels, T. (2014). Mentor teachers: Their perceived possibilities and challenges as mentor and teacher. Teaching and Teacher Education, 44, 106-116.

John-Steiner, V., \& Mahn, H. (1996). Sociocultural approaches to learning and development: A Vygotskian framework. Educational Psychologist, 31(3-4), 191-206.

Kagan, D. M. (1992). Implications of research on teacher belief. Educational Psychologist, 27(1), 65-90.

Khader, F. R. (2012). Teachers' pedagogical beliefs and actual classroom practices in social studies instruction. American International Journal of Contemporary Research, 2(1), 73-92.

Killian, J. E., \& Wilkins, E. A. (2009) Characteristics of highly effective cooperating teachers: A study of their backgrounds and preparation. Action in Teacher Education, 30(4), $67-83$

Kline, T. J. (2005). Psychological testing: A practical approach to design and evaluation. London, New Delhi: Sage Publications.

Krathwhol, D. R. (2002). Revising Bloom's taxonomy. Theory into Practice, 41(4), 212-218. Kuzborska, I. (2011). Links between teachers' beliefs and practices and research on reading. Reading in a Foreign Language, 23(1), 102-128. 
Lasky, S. (2005). A sociocultural approach to understanding teacher identity, agency and professional vulnerability in a context of secondary school reform. Teaching and Teacher Education, 21(8), 899-916.

Liu, L., Jones, P. E., \& Sadera, W. A. (2010). An investigation on experienced teachers' knowledge and perceptions of instructional theories and practices. Computers in the Schools: Interdisciplinary Journal of Practice, Theory, and Applied Research, 27(1), 20-34.

Loogma, K., Tafel-Viia, K., \& Ümarik, M. (2013). Conceptualising educational changes: A social innovation approach. Journal of Educational Change, 14(3), 283-231.

Löfström, E., \& Poom-Valickis, K. (2013). Beliefs about teaching: Persistent or malleable? A longitudinal study of prospective student teachers' beliefs. Teaching and Teacher Education, 35, 104-113.

Lunenberg, M. (2010). Characteristics, scholarship and research of teacher educators. In E. Baker, B. McGaw, \& P. Peterson (Eds.), International encyclopedia of education (3rd ed., Vol. 7, pp. 676-680). Oxford, UK: Elsevier.

Lunenberg, M., Korthagen, F., \& Swennen, A. (2007). The teacher educator as a role model. Teaching and Teacher Education, 23(5), 586-601.

Mansour, N. (2009). Science teachers' beliefs and practices: Issues, implications and research agenda. International Journal of Environmental and Science Education, 4(1), 25-48.

McCaslin, M., \& Hickey, D. T. (2001). Self-regulated learning and academic achievement: A Vygotskian view. In B. J. Zimmerman, \& D. H. Schunk (Eds.), Self-regulated learning and academic achievement: Theoretical perspectives (2nd ed., pp. 227-252). Mahwah, NJ: Lawrence Erlbaum Associates, Inc.

Meristo, M., Ljalikova, A., \& Löfström, E. (2013). Looking back on experienced teachers' reflections: How did pre-service school practice support the development of selfefficacy? European Journal of Teacher Education, 36(4), 428-444.

Ng, W., Nicholas, H., \& Williams, A. (2010). School experience influences on pre-service teachers' evolving beliefs about effective teaching. Teaching and Teacher Education, 26(2), 278-289.

OECD [The Organization for Economic Cooperation and Development] (2014). TALIS 2013 Results. An International Perspective on Teaching and Learning. Retrieved on 10 March, 2015 from: http://www.keepeek.com/Digital-Asset Management/oecd/education/talis-2013-results_9789264196261-en\#page1

Oldfather, P., \& Dahl, K. (1994). Toward a social constructivist reconceptualization of intrinsic motivation for literacy learning. Journal of Literacy Research, 26(2), 139-158.

Pajares, F. (1992). Teachers' beliefs and educational research: Cleaning up a messy construct. Review of Educational Research, 62(3), 307-332.

Rozelle, J. J., \& Wilson, S. M. (2012). Opening the black box of field experiences: How cooperating teachers' beliefs and practices shape student teachers' beliefs and practices. Teaching and Teacher Education, 28(8), 1196-1205.

Põhikooli riiklik õppekava (2011). [National Curriculum for Basic Schools; in Estonian]. Riigi Teataja, 06. jaanuar 2011, Vabariigi Valitsuse määrus, 1.

Rubie-Davies, C. M., Flint, A., \& McDonald, L. (2012). Teacher beliefs, teacher characteristics and school contextual factors: What are the relationships? British Journal of Educational Psychology, 82(2), 270-288.

Ruus, V. -R., Henno, I., Eisenschmidt, E., Loogma, K., Noorväli, H., Reiska, P., \& Rekkor, S. (2008). Reforms, developments and trends in Estonian education during recent decades. In J. Mikk, M. Veisson, \& P. Luik (Eds.), Reforms and innovations in Estonian education (pp. 11-26). Frankfurt am Main: Peter Lang Verlag. 
Sakk, M. (2014). Teachers' beliefs about how students cope at school. In A. Liimets, \& M. Veisson (Eds.), Teachers and youth in educational reality (pp. 81-102). Frankfurt: Peter Lang Verlag.

Salo A., Uibu K., Ugaste A. and Rasku-Puttonen, H., The question about effective teaching: educational students' and school-based teacher educators' beliefs about effective teaching practices, Procedia-Social and Behavioral Sciences 191, 2015, 2203-2212.

Sandholtz, J. H. (2011). Preservice teachers' conceptions of effective and ineffective teaching practices. Teacher Education Quarterly, 38(3), 27-47.

Sayeski, K., \& Paulsen, K. J. (2012). Student teacher evaluations of cooperating teachers as indices of effective mentoring. Teacher Education Quarterly, 39(2), 117-130.

Schmuck, R. A., \& Schmuck, P. A. (1975). Group processes in the classroom (2nd ed.). Dubuque, IA: Wm. C. Brown Company Publishers .

Simpson, T., Hastings, W., \& Hill, B. (2007). 'I knew that she was watching me': The professional benefits of mentoring. Teachers and Teaching: Theory and Practice, 13(5), 481-498.

Stipek, D. J., Givvin, K. B., Salmon, J. M., \& MacGyvers, V. L. (2001). Teachers' beliefs and practices related to mathematics instruction. Teaching and Teacher Education, 17(2), 213-226.

Stone, C. A. (1993). What is missing in the metaphor of scaffolding? In E. A. Forman, N. Minick, \& C. A. Stone (Eds.), Contexts for learning: Sociocultural dynamics in children's development (pp. 169-183). New York, NY: Oxford University Press.

Zwaans, A., van der Veen, I., Wolman, M., \& ten Dam, G. (2008). Social competence as an educational goal: The role of the ethnic composition and the urban environment of the school. Teaching and Teacher Education, 24(8), 2118-2131.

Tatto, M. T., \& Coupland, D. B. (2003). Teacher education and teachers' beliefs. In J. Raths, \& A. C. McAninch (Eds.), Teacher beliefs and classroom performance: The impact of teacher education (pp. 123-181). Greenwich, CT: Information Age Publishing.

Thomson, M. M., Turner, J. E., \& Nietfeld, J. E. (2012). A typological approach to investigate the teaching career decision: Motivations and beliefs about teaching of prospective teacher candidates. Teaching and Teacher Education, 28(3), 324-335.

Tillema, H. H., Smith, K. \& Leshem, S. (2011). Dual roles - conflicting purposes: A comparative study on perceptions on assessment in mentoring relations during practicum. European Journal of Teacher Education, 34(2), 139-159.

Timoštšuk, I., \& Ugaste, A. (2010). Student teachers' professional identity. Teaching and Teacher Education, 26, 1563-1570.

Toomela, A., \& Kikas, E. (2012). Children Studying in a Wrong Language: Russian-Speaking Children in Estonian School Twenty Years after the Collapse of the Soviet Union. Peter Lang Verlag. Frankurt am Main, Germany.

Tuul, M., Ugaste, A., \& Mikser, R. (2011). Teachers' perceptions of the curricula of the Soviet and post-Soviet eras: A case study of Estonian pre-school teachers. Journal of Curriculum Studies, 6, 759-781.

Uibu, K., \& Kikas, E. (2014). Authoritative and authoritarian-inconsistent teachers' preferences for teaching methods and instructional goals. Education 3-13, 42(1), $5-22$.

Uibu, K., Kikas, E., \& Tropp, K. (2011). Instructional approaches: differences between kindergarten und primary school teachers. Compare: A Journal of Comparative and International Education, 41(9), 91-111.

Valcke, M., Sang, G., Rots, I., \& Hermans, R. (2010). Taking prospective teachers beliefs into account in teacher education. In E. Baker, B. McGaw, \& P. Peterson (Eds.), 
International encyclopedia of education (3rd ed., Vol. 7, pp. 622-628). Oxford, UK: Elsevier.

van Huizen, P., van Oers, B., \& Wubbels, T. (2005). A Vygotskian perspective on teacher education. Journal of Curriculum Studies, 37(3), 267-290.

van Velzen, C., \& Volman, M. (2009). The activities of a school-based teacher educator: A theoretical and empirical exploration. European Journal of Teacher Education, 32(4), $345-367$.

Vaughn, M. (2014). Aligning visions: Striking a balance between personal convictions for teaching and instructional goals. The Educational Forum, 78(3), 305-313.

Viirpalu, P., Krull, E., \& Mikser, R. (2014). Investigating Estonian teachers' expectations for the General Education Curriculum. Journal of Teacher Education for Sustainability, 16(2), 54-70.

Vygotsky, L. S. (1978). Mind in society: The development of higher psychological processes. Cambridge, MA: Harvard University Press.

White, E., Dickerson, C., \& Weston, K. (2015). Developing an appreciation of what it means to be a school-based teacher educator. European Journal of Teacher Education, 38(4), 445-459.

Wilke, R. A., \& Losh, S. C. (2008). Beyond belief: Preservice teachers' planned instructional strategies. Action in Teacher Education, 30(3), 64-73.

\section{Appendix}

Examples of items on the questionnaire according to students' cognitive and social development.

Instructions: Please select the listed statements you consider essential when teaching. If a statement does not describe your teaching, leave it unmarked. You are welcome to add comments, if necessary.

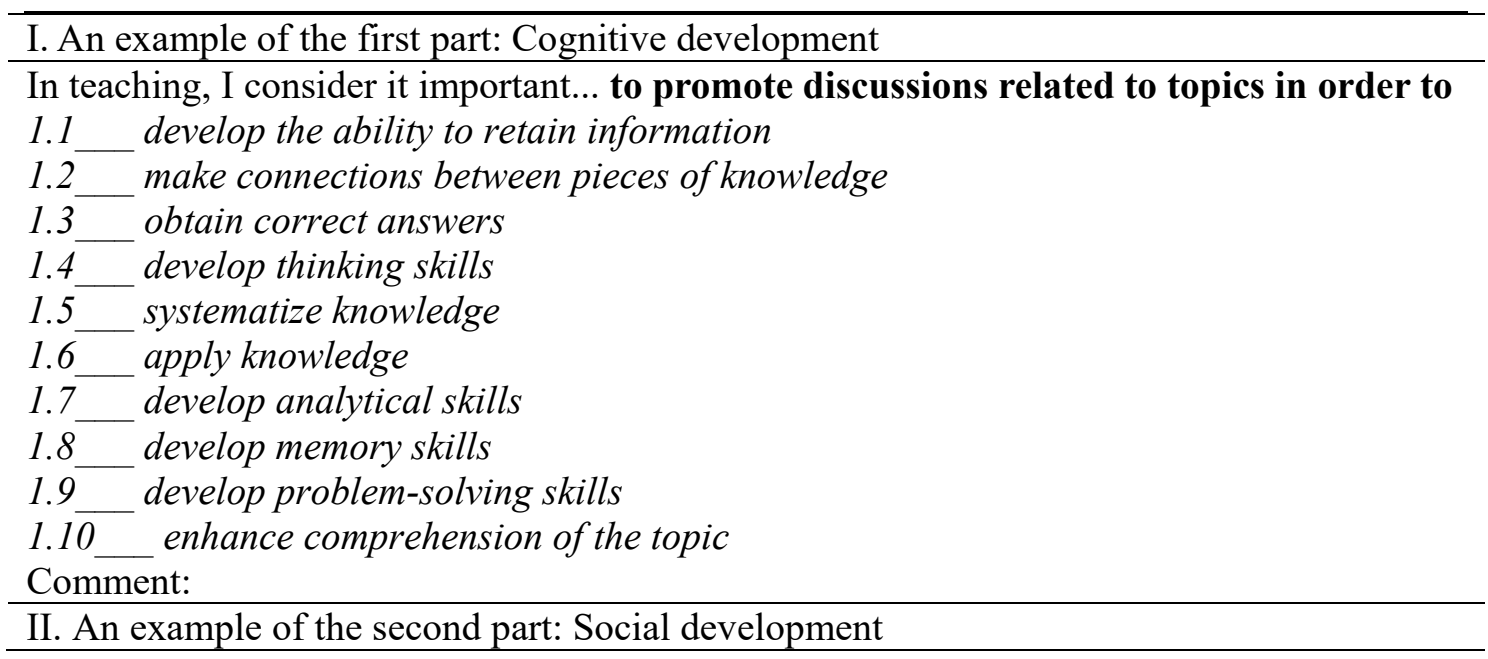




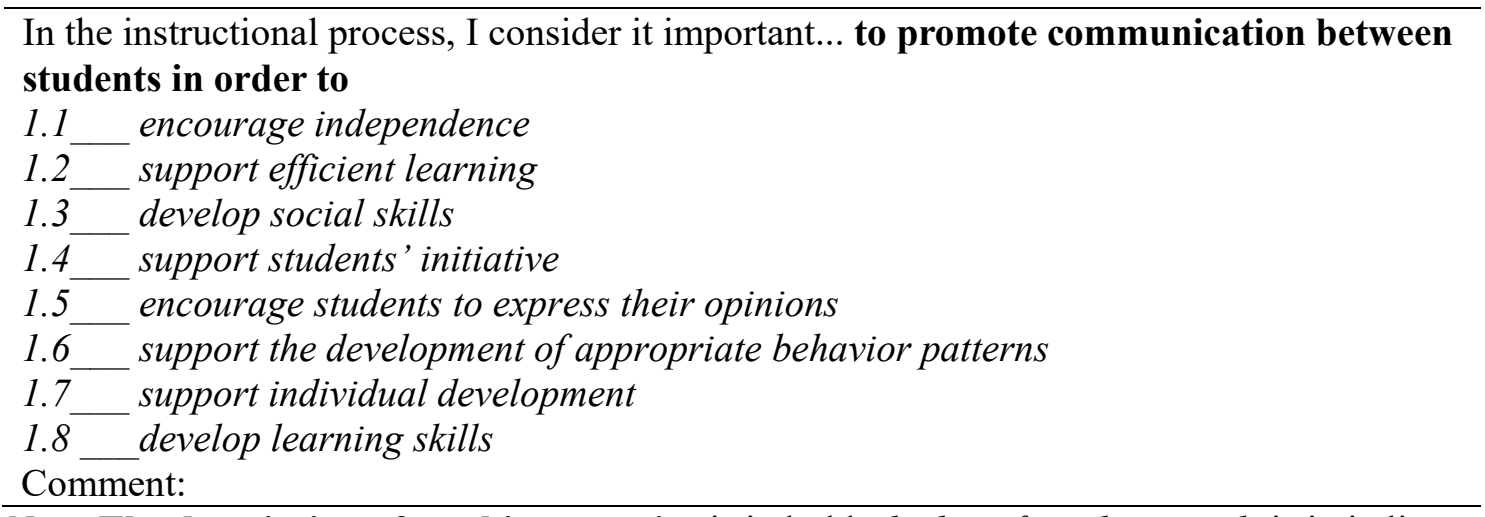

Note. The description of teaching practice is in bold; the list of teaching goals is in italics. 
Table 1

Beliefs about Teaching Goals and Teaching Practices by Students' and Teacher Educators' Experience Groups

\begin{tabular}{|c|c|c|c|c|c|c|c|c|c|c|c|}
\hline \multicolumn{12}{|c|}{ Teaching experience } \\
\hline \multirow[b]{2}{*}{ Teaching goals } & \multirow[b]{2}{*}{$\alpha$} & \multicolumn{2}{|c|}{$\begin{array}{c}\text { Students without } \\
\text { experience } \\
(N=92)\end{array}$} & \multicolumn{2}{|c|}{$\begin{array}{c}\text { Students with } \\
\text { experience } \\
(N=20)\end{array}$} & \multicolumn{2}{|c|}{$\begin{array}{l}\text { Teachers } \\
\text { TEG } 1 \\
(N=12)\end{array}$} & \multicolumn{2}{|c|}{$\begin{array}{c}\text { Teachers } \\
\text { TEG } 2 \\
(N=35)\end{array}$} & \multicolumn{2}{|c|}{$\begin{array}{c}\text { Teachers } \\
\text { TEG } 3 \\
(N=26)\end{array}$} \\
\hline & & $M$ & $S D$ & $M$ & $S D$ & $M$ & $S D$ & $M$ & $S D$ & $M$ & $S D$ \\
\hline I Cognitive development & $.85 * *$ & & & & & & & & & & \\
\hline $\begin{array}{l}1 \text { Mechanical acquisition } \\
2 \text { Implementation } \\
3 \text { Generalization } \\
\end{array}$ & $\begin{array}{l}.76^{*} \\
.75^{*} \\
.83^{*} \\
\end{array}$ & $\begin{array}{c}9.45 \\
17.79 \\
21.46 \\
\end{array}$ & $\begin{array}{l}5.24 \\
5.63 \\
7.42 \\
\end{array}$ & $\begin{array}{l}10.15 \\
18.80 \\
23.40\end{array}$ & $\begin{array}{l}5.54 \\
6.63 \\
8.41 \\
\end{array}$ & $\begin{array}{l}9.75 \\
16.83 \\
20.75 \\
\end{array}$ & $\begin{array}{l}6.52 \\
5.32 \\
6.78 \\
\end{array}$ & $\begin{array}{c}5.97 \\
16.66 \\
20.43 \\
\end{array}$ & $\begin{array}{l}3.98 \\
5.59 \\
6.74 \\
\end{array}$ & $\begin{array}{c}6.00 \\
17.65 \\
21.38 \\
\end{array}$ & $\begin{array}{l}5.64 \\
6.55 \\
8.11 \\
\end{array}$ \\
\hline II Social development & $.80^{* * *}$ & & & & & & & & & & \\
\hline $\begin{array}{l}1 \text { Independence } \\
2 \text { Reflexive skills } \\
3 \text { Social competence }\end{array}$ & $\begin{array}{l}.75^{*} \\
.72^{*} \\
.61^{*} \\
\end{array}$ & $\begin{array}{c}8.73 \\
10.40 \\
6.95 \\
\end{array}$ & $\begin{array}{l}3.97 \\
4.65 \\
2.37 \\
\end{array}$ & $\begin{array}{c}9.40 \\
11.80 \\
7.15 \\
\end{array}$ & $\begin{array}{l}4.93 \\
5.11 \\
2.70\end{array}$ & $\begin{array}{l}8.58 \\
9.75 \\
6.58 \\
\end{array}$ & $\begin{array}{l}4.23 \\
4.16 \\
2.11\end{array}$ & $\begin{array}{c}8.49 \\
11.43 \\
6.86 \\
\end{array}$ & $\begin{array}{l}3.69 \\
4.15 \\
1.97 \\
\end{array}$ & $\begin{array}{c}9.65 \\
11.38 \\
7.69 \\
\end{array}$ & $\begin{array}{l}3.56 \\
3.59 \\
2.09\end{array}$ \\
\hline Teaching practices & & & & & & & & & & & \\
\hline I Cognitive development & $.76^{* *}$ & & & & & & & & & & \\
\hline $\begin{array}{l}1 \text { Intrapersonal practices } \\
2 \text { Interpersonal practices }\end{array}$ & $\begin{array}{l}.82^{*} \\
.76^{*} \\
\end{array}$ & $\begin{array}{l}33.09 \\
15.61 \\
\end{array}$ & $\begin{array}{c}11.24 \\
5.91 \\
\end{array}$ & $\begin{array}{l}35.25 \\
17.10 \\
\end{array}$ & $\begin{array}{c}13.68 \\
6.56 \\
\end{array}$ & $\begin{array}{l}33.83 \\
13.50 \\
\end{array}$ & $\begin{array}{l}13.57 \\
3.63 \\
\end{array}$ & $\begin{array}{l}30.57 \\
12.49 \\
\end{array}$ & $\begin{array}{c}10.05 \\
4.84\end{array}$ & $\begin{array}{l}31.46 \\
13.58 \\
\end{array}$ & $\begin{array}{r}12.47 \\
6.56 \\
\end{array}$ \\
\hline II Social development & $.83 * *$ & & & & & & & & & & \\
\hline $\begin{array}{l}1 \text { Intrapersonal practices } \\
2 \text { Interpersonal practices }\end{array}$ & $\begin{array}{l}.67^{*} \\
.78^{*}\end{array}$ & $\begin{array}{l}13.98 \\
12.10 \\
\end{array}$ & $\begin{array}{l}5.60 \\
4.71 \\
\end{array}$ & $\begin{array}{l}15.45 \\
12.90\end{array}$ & $\begin{array}{l}6.86 \\
5.23 \\
\end{array}$ & $\begin{array}{l}14.58 \\
10.33 \\
\end{array}$ & $\begin{array}{l}5.44 \\
3.92 \\
\end{array}$ & $\begin{array}{l}15.14 \\
11.63 \\
\end{array}$ & $\begin{array}{l}5.09 \\
4.12 \\
\end{array}$ & $\begin{array}{l}16.23 \\
12.50\end{array}$ & $\begin{array}{l}6.56 \\
4.24 \\
\end{array}$ \\
\hline
\end{tabular}

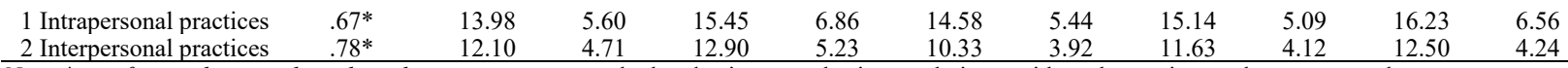

2 Interpersonal practices ${ }_{\text {Note. }}^{*}=\alpha$ for teaching goals and teaching practices was calculated using tetrachoric correlations, with each practice as chosen or not chosen.

$* *=\alpha$ for cognitive and social development was calculated using Pearson correlations with all respective goals of the scale.

TEG 1 - the first teachers' experience group; TEG 2 - the second teachers' experience group; TEG 3 - the third teachers' experience group. 
Table 2

Teachers' Beliefs about Teaching Goals According to Mentoring Experience

\begin{tabular}{lcccc}
\hline & \multicolumn{4}{c}{ Mentoring experience } \\
\cline { 2 - 5 } & $\begin{array}{c}\text { Teachers without } \\
\text { mentoring experience } \\
(N=18)\end{array}$ & $\begin{array}{c}\text { Teachers with mentoring } \\
\text { experience } \\
(N=55)\end{array}$ \\
\cline { 2 - 5 } Teaching goals & $M$ & $S D$ & $M$ & $S D$ \\
\hline I Cognitive development & & & & \\
1 Mechanical acquisition & 7.00 & 6.62 & 6.47 & 4.70 \\
2 Implementation & 15.44 & 6.97 & 17.56 & 5.40 \\
3 Generalization & 19.00 & 7.73 & 21.42 & 6.96 \\
\hline II Social development & & & & \\
1 Independence & 8.00 & 4.00 & 9.22 & 3.61 \\
2 Reflexive skills & 9.33 & 3.16 & 11.73 & 3.94 \\
3 Social competence & 6.11 & 2.03 & 7.44 & 1.98 \\
\hline
\end{tabular}

Table 3

Teachers' Beliefs about Teaching Practices in Two Groups of Mentoring Experiences

\begin{tabular}{|c|c|}
\hline \multicolumn{2}{|c|}{ Mentoring experience } \\
\hline $\begin{array}{c}\text { Teachers without } \\
\text { mentoring experience } \\
\qquad(N=18)\end{array}$ & $\begin{array}{c}\text { Teachers with mentoring } \\
\text { experience } \\
(N=55)\end{array}$ \\
\hline$S D$ & $S D$ \\
\hline
\end{tabular}

\begin{tabular}{lcccc}
\hline Teaching practices & & & & \\
\hline I Cognitive development & & & & \\
1 Intrapersonal practices & 28.78 & 14.92 & 32.29 & 10.09 \\
2 Interpersonal practices & 12.67 & 5.91 & 13.16 & 5.25 \\
\hline II Social development & & & & \\
1 Intrapersonal practices & 13.72 & 5.33 & 16.00 & 4.75 \\
2 Interpersonal practices & 9.72 & 3.60 & 12.88 & 4.12 \\
\hline
\end{tabular}

